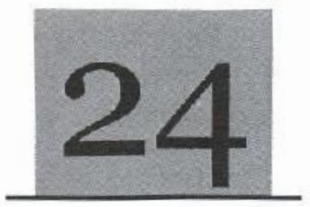

\title{
Technology for the culture of marine fish species: prospects and implementation in Nigeria
}

\author{
Francis, A. / Davis, C. I.
}

\section{Abstract}

Greater pmportion of the much needed rich animat protein und other essential nulrients for man 's prolonged well-being, globally, is derived from fish. Three considered factors in production model for such aquacuiture project include: the technology, suitable site for location of envisaged set up and market. While concerned and interested stakeholders can bring logether the intelligentsia for such venture, the government can provide enabling environment. Noting that the adopted technology will consist of hardware lequipment and structures) and software (relevant human resource and globally accepted procedures), technology for the production of marine fish species can be assembled in Nigeria since there are enginetrs of various disciplines, fisheries researchers, fish farmers, hatchery opera tors, lechnologists, technicians, numerous marine and brackish water shell and fin fishes and several kilomeires of coastai area. There are industries that can fabricate various aspects of the facilities and equipment, knowing full well that corrasion free and non-toxic materials are a must for fish breeding operations. The challenge for regular power supply can be overcome by turning to alternative energy sources such as solar energy, or from sources such as gas, wind, or water, these being abundant in Nigeria. The first step in efforts to establish technology for the culiure of marine fish in Nigeria and boost proctuction in the face of dwindling production from the wild should be a review of literature and spirited efforts to adapt such for the nation. This paper focuses on success made so far in the culture of marine fish species in same parts of the world, and necessary steps to ensure their establishment in Nigeria.

Keywords: Marine fish culture and technology, prospects.

\section{Introduction}

T

he indispensability of the fishery resource in contributing to food and nutrition security and other socio-economic development has led to its increase in production and trade (Dutta, 2000, Philips, 2009). Production from aquaculturc augmented the experienced decreased supply from the wild (IIardy, 1999; Laing, 2009; Philips, 2009). Globally there is evidence that majority of fish stocks will be over fished and increasingly impacted by degraded aquatic environment due mainly to anthropogenic activities (McWhinnie and Fernandes, 2011), climatic and environmental factors. Newer technologies have been put in place to improve the state of fish production in captivity (Reddy and Dwivedi, 1986 and Schulstad, 1997) and to manage natural stocks in better ways, thus increasing and sustaining the supply of fish for consumption and socio-economic benefits, while still ensuring conservation of genetic biodiversity (Leber, 2004). There is need for awareness creation on the development of technology for the production of brackish water and marine fish species for coastal aquaculture in Nigeria, in addition to the commonly cultured fresh water cattish Clarias sp., which is not so accepted by the coastal populace in Nigeria. Such technology when established will greatly contribute to food and nutrition security, socio-economic development, conservation of the fishery resource, the aquatic environment at large, and ensure sustainability. Most fresh water fishes can reproduce in captivity and readily grow to table size, but contrary for the marine ones that require more careful procedures in terms of obtaining brood stocks and conditioning to optimum breeding and environmental conditions, getting the right medium for fertilization, establishing efficient means of transportation, and formulation of feed with high feed conversion ratio that will translate into high specific growth rate. Millions of reared marine fish juveniles have been released into the coastal waters since the 1970s in Japan and other Asian countries (Takebe, 2000; Bartley and Leber, 2004).

This paper focuses on efforts that have been made so far in the culture of marine fish species in certain parts of the world, and in the face of huge available potentials in Nigeria, proffer steps for the establishment of such in the nation. 


\section{Successfully Cultured Marine Fish Species: Lessons from Asian Countries}

Zhong and Zhang (2003), reporting on the culture of marine fish species noted that species belonging to about 24 families have been successfully cultured at high production rates, and which include the grunts (species of Haemulidae/Pomadasyidae), sleepers (species of Serranidae), drums/croakers (species of Sciaenidae), flounder (species of Bothidac), mullcts (species of Mugilidae), milkfish (Chanos chanos), snappers (species of Lutjanidae) etc, all of which are present in Nigerian marine ecosystems. According to Boonyaratpalin (1997), culture of marine and brackish water fish species is an important venture in South East Asia and through this venture contribution to global sea food and live fish trade has expanded. The fish farmers prefer the hatchery reared fry to the wild caught due to the high survival and growth rates of the cultured ones (Mills, 2001). Researchers and hatchery owners collaborate in the artificial rearing; various localities specialising in breeding particular fish species and can then export to other regions (Yeh and Ting, 1990; Yeh et al., 1991: Yeh et al., 1995). The hatehery farmers make use of live food and atimes include use of the green microalgae (Nannochloropsis sp.) in larval rearing tanks for the control of water quality and transparency. The establishment of many hatcheries based on their locally available species promoted the rapid growth of aquaculture in Asia. The major fish feeds were trash fish and artificial feed that were given in the form of dry or moist pellets. Very high survival rates were recorded through the use of indoor hatchery system. (Lin et al., 1979; Tang et al., 1979a; 1979b; 1979c; Liu and Hu, 1980).

\section{Dynamics of Marine Fish and Shell Fish Cultures}

Factors that will determine efficiency in the production of brackish water and marine fish species can be grouped under: Adopted Technology, environmental considerations and market forces in fish trade.

Technology for the culture of marine fish species in Nigeria: A critical factor in the success of aquaculture of marine fishes in $\Lambda$ sia has been the establishment of lots of viable hatcheries (Gupta and Gupta, 2008). Fish seed is an indispensible input for increased fish production; hence its availability will determine the viability and success of large scale aquaculture or mariculture. In the wild, percentage of hatched eggs that attain the adult size is low due to adverse environmental conditions and predators (insects, fish, frogs, snakes, birds etc.) that reduce the survival of offspring. Contrariwise, higher percentage of artificially reared offspring grow to table size with proper handling, and even do better than seed collected from the wild, which is no longer in vogue in Asia (Gupta and Gupta, 2008). Marine fishes can be reared on land or within the wild aquatic ecosystem (Philips, 2009), in fresh water or marine environments such as in paddy ponds, tidal ponds, excavated ponds from other uses, earthen ponds, concrete tanks, pens, cages, raceways and recirculatory system. Production components which consist of hardware (facilities, equipment and structures) and software (current standardized procedures, and efficient skilled man-power) can be formed. The machines should generally be affordable, corrosion-free and non toxic materials (Jadhav, 2009).

An up to date hatchery for mass production of marine fishes, therefore will consist of all necessary units such as: brood tanks, facilities for handling the spawners, incubators, spawning tanks with all its facilities, feed dispensers, larval rearing tanks, aerators, nets, conditioning tanks, hapas etc. The grow-out system of the fish farm could be any of these or a combination: pens, cages, concrete tanks etc. as listed above. For a feasible and growing fish trade, efficient means of live fish transport is a necessity; and it has to do with the use of live seed carriers (vehicle) for long distances or $3 / 4$ oxygen-filled polythene bags for short distances. Other pot-like or basin-like open containers are also used (Gupta and Gupta, 2008). Prior to seed transport, appropriate water temperature, dissolved oxygen content, stocking density and possible fresh water exchange during transportation are usually considered. Anesthetics (MS-222, Urethane and 2-methyl-quinoline) may be needed just to decrease metabolism and movement of the fry, night being the best time for such movements (Gupta and Gupta, 2008).

Most of the farmers use eage for mariculture, they buy good quality fry of same size from producers, acelimate to artificial feed and transfer to cages by size $9-10 \mathrm{~cm}$ (FBA, 1998).

Environmental considerations: Environmental characteristics of a chosen site will determine the type of hatchery model and grow out system to use (Laing, 2009; Alvarez-Lajonchere and Perez-Loa, 2012; Troell et al., 2013). Besides, source of good quality and adequate water supply that falls within the range for optimum fish production is a factor of top priority in locating marine fish farms; they should best be located by the coastal area where large volumes of sea water will be available for use. Marine fishes grow best in waters that are very stable in quality (Mills, 2001). Apart from the quality of seawater, which can be controlled within certain limits by means of screens, filters, settling tanks, sterilization equipment, etc., the other main factors to manipulate are air and water temperatures as these also affect production. For instance, in northern Italy and along the French Mediterranean coast, sea bass reaches marketable size of $250-350 \mathrm{~g}$ in 20 to 24 months; and 16 to 20 months for the gilthead sea bream. For the African Mediterranean coast, however, the period needed to reach these sizes is reduced to 14 to 15 months for sea bass, and a year for the gilthead sea bream. During the freezing conditions of winter in the northern Mediterranean, precautions are usually taken to avoid stoppage in growth and complete death of all the fishes by provision of appropriate facilities, such as wintering ponds, greenhouses, water heating systems, etc.

Knowing the adverse effect of winter, farmers, in stocking their cages avoid two winter seasons per production cycle. In regions with such adverse winter conditions, fry production is concentrated during summer for about two months, but demand and purchase of the fry is usually spread over many months in regions without adverse winter, and farmers therefore can have more production cycles (Alvarez-Lajonchere et al., 2007).

Challenge posed by adverse condition on seed production actually led to technological solutions such as the use of water re-circulatory systems, and computerized system Schulstad (1997) for the control, monitoring and management of en- 
virommental parameters, which include oxygen, $\mathrm{pH}$, nitrites and nitrates. In India, fish brecding is not restricted to season; it is done under controlled condition (Reddy and Dwivedi, 1986) in the hatchery. The lesson for Nigeria is that farmers should intensify the stocking of their ponds during the rainy season when the weather is cool and manipulate the environment as the need arises. Other factors to take into consideration while siting marine fish farm include transportation of produce, accessibility and market.

Trade in marine fishery resource: Definitely, there will be market for cultured marine fish species in Nigeria and beyond since the coastal populace love the taste of brackish water and marine fishes. Restaurants, fast food places and hotels can be targeted as distribution points along the distribution nctwork. Production and harvest can be arranged to target the peak periods of celebration. The market may drive the hatchery and grow-out outputs, and both linked by price of the fish and demand. Faster and cleaner means of transport has increased trade in live fish globally. Value addition in the fishery resource such as drying, smoking, filleting and packaging in various ways have all opened up trade in the fishery sub-sector.

Prospects and Indispensable Steps in Establishing Technology for Culture of Marine Fish Species in Nigeria The culture of marinc fish species can be a possibility in Nigeria if all the available potentials can be harnessed. One of the major steps in the bid to establish this technology should involve carrying out more biological and ecological studies, and review of literature to ascertain life cycle of culturable marine fish species in Nigerian marine waters. Next, would be to package propagation procedures, care of larvae, fry, fingerling, and post juveniles to table size; while viable and genetically diverse brood stocks would be sustained in banks. Best method of live sced transport per fish speeies, as well as appropriate feed must be formulated for each stage of the fish species, that is, for larvae, fry, fingerling and adults. Harvesting procedures, value added processes, storage facilities, distribution channels and market for fingerlings and table fish should be mapped out to ensure optimum benefits from end products of the technology. To establish marketing chains and outlets, survey can be undertaken to ensure that outlets and markets exist for the disposal of products; hence production can also commence on a pilot scale. According to Alvarez-Lajonchère et al, (2012) technology which consists of hardware (facilitics and equipments) and software (skilled personncl and globally accepled standards) and is central to the culture of marine fish species, the potential of its asscmblage in Nigeria is very high. The teeming population of engineers of various disciplines, fisheries researchers (biologists and ecologists), scasoned aquaculturists, technologists, technicians, and thousands of kilometres of low lying coastline containing billion cubic metres of marine water pose as great potentials to tap into. Industries that can fabricate various aspects of the fish farm facilities and equipment, knowing full well that corrosion free and non-toxic materials are a must for fish breeding operations can be sourced for. Regular power supply, which is basic to the viability of such ventures, can be overcome by tuming to alternative energy sources such as solar encrgy, gas, wind, or water as the case may be. The following areas of research will need to be given attention: maintenance of viable brood stocks bank, production and rearing of fry and juveniles, management of grow out, nutrition for juveniles and adult, proximate and acid profile analysis of cultured fish flest, and genetics. One of the challenges faced in aquaculture or mariculture is occurrence and transfer of disease. Appropriate preventive measures have to be put in place, and which mostly has to do with absolute cleanliness and hygienic conditions especially at points of transfers and contact with the fishery resource. It has to be ensured that only the healthy cultured fishery resource is stocked (Leber, 2004).

\section{Conclusion}

Besides the commonly cultured fresh water cattish in Nigeria, scveral marine shell and fin fish species can be cultured in Nigeria since these have also being successfully cultured in Asian countries. With the privilege of hindsight the major goal in establishing marine fish culture should be the optimum and sustainable production of these fishery resources, especially rare or threatened species, with due consideration to the health of the aquatic environment. In rearing cultured fishes in the natural aquatic environment (mariculture), caution is needful because transfer of diseases are usually rife in densely populated stocks of fishes; in addition, pollution of the ccosystem can result from feed remnant, and alter water quality. Vast potentials such as availability of skilled and efficient engineers, fisheries scientists, aquaculturists, etc are on ground and can harness the available rusources for culture of marine fishes in Nigeria. Strategically located hatchery with its complete units will form solid bedrock on which the technology can rest and thrive. Sarotherodon mclanotheron, Tilapia guineensis, the croakers Pseudotolithus spp., the snappcrs Lutjanus spp. and the groupers Epinephelus etc are all prospective entrants into aquaculture in Nigeria. While concerned and interested stakeholders will bring together the intelligentsia for such venture through various fora, the government can give support for the provision of enabling environment. Focused research on the biology and ecology of prospective marine fish species for culture, and the various disciples of aquaculture should be cncouraged in institutions of higher learning.

\section{REFERENCES}

Aquaculture and Inland Fisheries Project (AIFP), (2005). Overview of Fisheries in Nigeria. Newsletter of the Aquuculture and Inland Fisheries Project of the National Special Task Forte for Foad Security in Nigeria. Technical Note 16.

Alvarez-I ajonchere, L.; Reina Canez, M.A.; Camacho Hemandz, M.A.; Kraul, S. (2007). Design of a pilot scale tropical marine fin fish hatchery for a research centre at Mazatlan, Mexico. Aquacultural Engineering. 36(2): 81-96.

Alvarez-Lajonchere, L. and Perez-Roa, R. (2012). Site selection for tropical marine fish hatchery and its application in the Carribean Coast of Nicaragua. Aquacuitural Engineering, 48: 10-17 
Barker, H.C. (1986). Investment Opportunities in Fish Seed Technology. Fisheries Society of Nigeria (FISON) Conference Proceedings. Boonyaratpalin, M. (1997). Nutrient requirements of marine food fish cultured in South East Asia. Aquaculture. 151(1-2): 283-313. Bartley and Leber (eds.) Marine Ranching, FAO Fisheries Tech. pap., Rome. 429: 203-213.

Dutta, O.K. (2000). An Overview on the Status of Fish Seed Production in Assam College of Fisheries, Assam Agricultural University, Raha, Nagaon, Assam, India. No. 3: 1-4p.

FBA (1998). Field survey of fish seed production. Fish Breeding Association of Republic of China (unpublished survey data shcets). Huang, T. and 4 co-authors. (1986) Experiments on treatment, ovulation of spawners and embryos of black-spotted grouper, Epinephehus salmonoides. Bull. Taiwan Fish. Res. Inst. 40: 241-257.

Gupta, S.K. and Gupta, P.C. (2008)General and Applied Ichthyology(Fish and Fisheries). S. Chand and Company, Rum Nurgar, New Delhi, 1133pp.

Hardy, R.W. (1999). Collaborative opportunities between fish nutrition and other disciplines in aquaculture: An overview. Aquaculture. 177(1-4):217-230.

Jadhav, U. (2009). Aquaculture Technology and Environment. PIII Learning Private Lid, New Delhi, 334pp.

Laing, I. (2009). Oysters- Shellfish farming. Encyclopedia of Earth sciences, $2^{\text {nd }}$ Edition. Pp: 274-286.

I eber, K.M. (2004). Summary of case studies on the effectiveness of stocking aquacultured fishcs and invertebrates to replenish and enhance coastal fisheries. In: Bartley and Leber (cds.) Marine Ranching, FAO Fisheries Tech, paper, Rome. 429: 203-213.

Lin, K.J.; Yen, J.L. and Su, W.C. (1979) Preliminary report on the artificial propagation of the red sea bream, Chrysophrys major. China Fish. Mon. 320: 3-8.

Liu, F.G. and IIu, S.H. (1980) Preliminary report on the artificial fertilization and incubation of yellowfin porgy, Acanthopagrus latus. Bull. Taiwan Fish. Res. Inst. 32: 673-678

McWhinnie, L. and Fernandes, T.F. (2011). The culture of aquatic species: Systems and future developments. Estuarine and Coastal Science. Pp: 277-301.

Mills, D. (2001). An essential guide to choosing your marine tropical fish. Interpet Publishing, England, 73pp.

Philips, M. (2009). Mariculture overview. Encyclopedia of ocean sciences, $2^{\text {td }}$ Edition. Pp: 537-544.

Pillay, T.V.R. (1990). Aquaculture principles and practices. Fishing New Books, Blackwell Puplbishing, 575pp.

Reddy, A. and Dwivedi, S.N. (1986).Fish breeding in a controlled environment-Carp hatchery, CIFE-D81. Aquaculture. 54(1-2): 27-36.

Salvannes, A.G.V. (2001). Ocean Ranching, Fncyclopedia of ocean sciences. Elsevier lid, $1^{\text {st }}$ Edition. Vol 4: $1973-1982$.

Schulstad, G. (1997). Design of a computerized decision support system for hatchery production management. Aquacultural Engineering. $16(1-2): 7-25$

Takebe, T. (2000). Japanesc sca fish production in 1998. Saibai, 94:30-39.

Tang, II.C.; Twu, J. and Su, W. (1979a). Preliminury report on artificial propagation of black-spotted grouper, Epinepheitus amblycephalus, Bull. Taiwan Fish. Res. Inst 31: 511-517.

; Twu, J.Y. and Su, W.C. (1979b). Experiments on the artificial propagation of black porgy, Acanihopagrus schlegeli - (1) Hormone treatment and ovulation of spawners. China Fish. Mon. 319: 9-14.

; Twu, J.Y. and Su, W.C. (1979c). Experiments on the artificial propagation of black porgy, Acanthopagrus schlegeli - (2) Fertilization, hatching and larvae breeding. China Fish. Mon. 322: 3-10.

Troell, M.; Kautsky, N.; Beveridge, M.; Henriksson, P.; Primavera, J.; R nnback, P. and Folke C. (2013). Encyclopedia of Biodiversity, $2^{\text {nd }}$ Edition. Pp: 189-201.

Yeh S.L. and Ting, Y.Y. (1990). Studies on the reproduction for broodstock establishment of groupers. Bull. Tuiwan Fish. Res. Inst. 49: $167-181$.

; Chu, Y.T. and Ting, Y.Y. (1991). Studies on the artifical propagation for broodstock establishment of groupers-the embryonic development of blue-spotted grouper (E. faria) and comparing with hybrid ( E. fario X E. malabaricus ). Bull. Tuiwan Fish. Res. Inst. 50: 197-216.

; Chu, Y.T; Hseu, J.R. and Ting, Y.Y. (1995). Effects of salinity on development of the grouper Epinephelus coioides embryo before and post organogenesis. J. Taiwan Fish. Res. 3(2): 133-142.

Zhong, W. and Zhang, Q. (2003). Review of captive bred species and try production of marine fish in China. Aquaculture. 227(1-4): 305-318. 